\title{
Devonian graptolites from southwestern Europe: a review with new data
}

\author{
A. C. LENZ ${ }^{1}$, M. ROBARDET ${ }^{2}$, J. C. GUTIÉRREZ-MARCO ${ }^{3}$ and J. M. PICARRA 4 \\ ${ }^{1}$ Department of Earth Sciences, University of Western Ontario, London, Ontario. Canada N6A $5 B 7$ \\ ${ }^{2}$ Institut de Géologie, Université de Rennes I, and URA 1364 CNRS, 35042 Rennes Cedex. France \\ 3 Instituto de Geología Económica (CSIC-UCM), Facultad de Ciencias Geológicas, 28040 Madrid, Spain \\ ${ }^{4}$ /nstituto Geológico e Mineiro, Department de Geologia, Ap. 104, 7802 Beja Codex, Portugal
}

Lower Devonian graptolite faunas have been recognized in the Normandy and southeastern regions of the Armorican Massif, France; the Pyrenees and Catalonian Coastal Ranges regions and northern Minorca, Balearic Islands, Spain; the southern Hesperian Massif (Ossa Morena Zone) of the Iberian Peninsula; and from southeastern Sardinia, Italy. All but one the of the graptolite faunas collected throughout this large region are from Lochkovian age strata, representing the Monograptus uniformis, Monograptus prachercynicus, and Monograptus hercynicus biozones corresponding to the lower. middle and upper Lochkovian, respectively, and mostly represented by monospecific or low diversity assemblages. Although many individual sections contain representatives of two of the biozones, relatively few reveal all three. A single, poorly preserved faunule. collected in the Ossa Morena region of Spain from strata dated by brachiopods as Pragian-early Emsian may represent the only known graptoloid fauna of post-Lochkovian age.

Almost all graptolites have been recovered from condensed successions of black shales and limestone nodules, similar to those of other proto-Tethyan (i.e. outer shelf, with dominantly pelagic faunas) regions such as Thuringia, Bohemia, the Carnic Alps and northwestern Africa. The two exceptions are an occurrence in a shallow-water, coarser clastic sequences at the Carteret locality in Normandy and in deep water turbidites on the island of Minorca. Graptolites are not known from any other thick, shallow water clastic sequences, although whether this is because of paleo environmental exclusion or simply lack of recovery to date is unknown. Other fossil evidence (e.g. chitinozoans), however, indicates continuous marine sedimentation from the Silurian to Devonian. 1996 by John Wiley \& Sons. Ltd.

Recented 21 August 1995: Accepted 15 February 1996

Gcol. J. 31. 349-- 358, (1997)

No. of Figures: 7. No. of Tables: 0. No. of Refs: 33.

KEY WORDS graptolites; Lower Devonian: France; Spain, Italy; Iberia: Sardinia; biostratigraphy: Lochkovian

\section{INTRODUCTION}

Devonian graptolites are known from diverse localities of the French Armorican Massif, the southern Hesperian Massif of Spain, the Palaeozoic basement of the Spanish Alpine belt and from southern Sardinia. The first records of what have subsequently been recognized as Devonian graptolites in southwestern Europe were collected from France (Péneau 1944; Philippot 1950) and Spain (Bourrouilh 1963), all of whom identified them as common silurian species (e.g. Monograptus riccartonensis, M. flemingii primus, $M$. vomerinus crenulatus). Distinctive Devonian forms ( $M$. hercynicus, $M$. uniformis, $M$. praehercynicus) were later reported from Silurian-Devonian sequences in the Catalonian Coastal Ranges (Greiling and Puschmann 1965) and central Pyrenees (Llopis and Rosell 1968), although at the time these faunas were still considered to be of late Silurian, post-Ludlow age. The first actual recognition of Devonian graptolites in southwestern Europe stems mainly from the taxonomic studies of H. Jaeger, whose identifications were incorporated into several papers on regional geology and stratigraphy. The only descriptions and/or illustrations of Devonian graptolites in this region are by Bourrouilh $(1963,1983)$, Jaeger and Robardet 


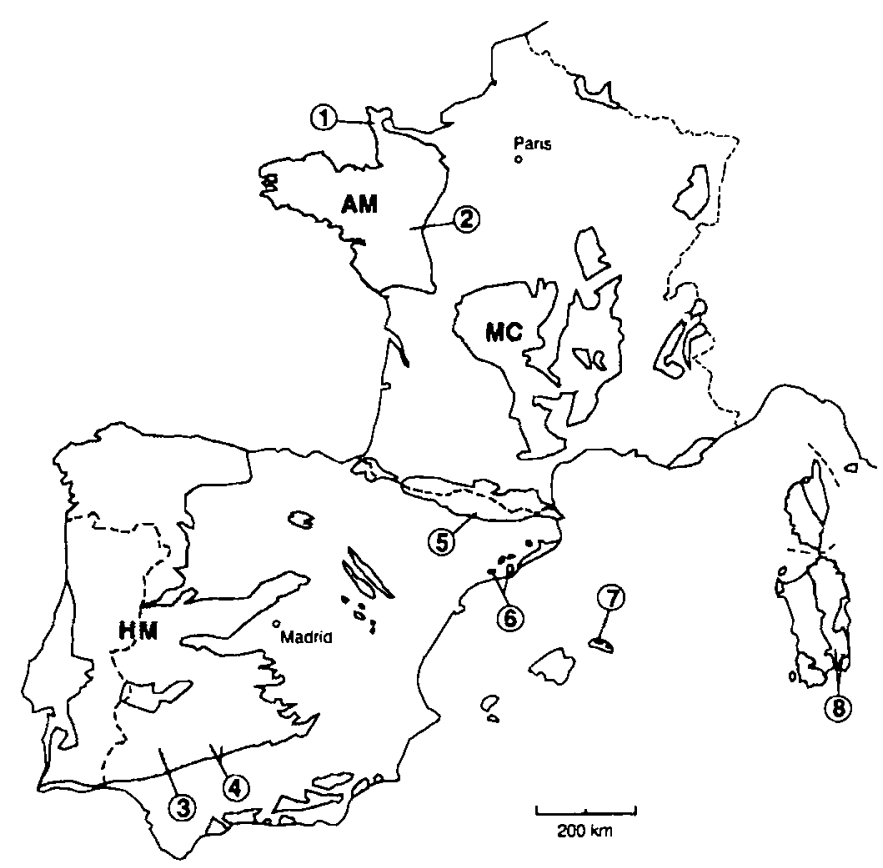

Figure 1. Devonian gruptolite localities in southwestern Europe. AM. Armorican Massif: MC. Massif Central: HM, Hesperian Massif. I. Carteret, Normandy: 2. La Meignanne, SE Armorican Massif, 3, Venta del Ciero, Ossa Morrena Zone; 4, Valle and Cerrón del Hornillo synclines, Ossa Morena Zone; 5, Gerri de la Sal. central Pyrenees; 6. Miramar and Barcelona area, Catalonian Coastal Ranges; 7, northern Minorca. Balearic Islands; and 8. Goni and Baccu Scottis. SE Sardinia

(1973, 1979), Jaegar (1976). Rickards and Chapman in Julivert et al. (1985), Oczlon (1989. unpublished data), and Rickards et al. (1995).

The aim of this paper is to provide a synthesis, updated assessment and an overview of the present state of knowledge of Devonian graptolites of Spain and France, where most of the localities occur, along with a short discussion of the island of Sardinia, Italy (Figure 1).

\section{$2 a$ Normandy}

\section{ARMORICAN MASSIF}

Monograptus uniformis Pŕibyl (Fig. 6) and, questionably, M. uniformis angustidens Př́byl were reported from $1 \mathrm{~km} \mathrm{NNE}$ of the village of Carteret in northwestern Normandy (Cotentin Peninsula; Figure 1, locality 1) (Jaeger and Robardet 1973). The graptolites were found in black shales in the uppermost part of the Saint-Germain-sur-Ay Formation, a succession of alternating sandstones and shales. They are separated by a small, but unknown, interval from the overlying, sandstone-dominated, La Haye-du-Puits Formation, dated by chitinozoans as of early Lochkovian age (Paris 1981). The same fossiliferous interval also yielded scyphocrinoid and ceratiocarid remains and bivalves (Babin and Robardet 1974). The state of preservation of the very thin shells, with details of ornamentation, indicates a quiet environment and very limited transport. These alternating shales and sandstones do not show any of the characteristics of turbidites; they correspond to inner shelf shallow water deposits in which the upwards increase in sandy terriginous influx culminates in the sandstones of the overlying La Haye-du-Puits Formation.

\section{2b. Southeastern Armorican Massif: La Meignanne locality}

Monograptus uniformis was identified by Jaeger (in Paris 1981) from a collection of black, calcareous claystones from the La Meignanne quarry near Angers (Figure 1, locality 2). The sequence comprises an 
unknown thickness of Ludlow to Lochkovian age, probable offshore facies, black, argillaceous limestones that are highly tectonized and are envisaged to be of allochtonous origin (Křiž and Paris 1982). They contain bivalves, cephalopods and chitinozoans, as well as graptolites.

\section{HESPERIAN MASSIF}

Devonian graptolites are known only in the southern segment (Ossa Morena Zone) of the large west Iberian Massif, where a distinctive and continuous Silurian-Devonian succession in the graptolitic facies shows a striking similarity to coeval sequences of 'Mediterranean type' facies (Thuringia, Carnic Alps, Algeria, Sardinia). Most of the graptolites were collected from the upper half of the 'Upper Graptolitic Shales' that overlie Pridoli limestones in two small synclines north of the Seville Province.

\section{Cerrón del Hornillo syncline}

Devonian graptolites have been identified from several levels in two separate sections (sections 2 and 3 , Figure 5, in Jaeger and Robardet 1979; Figures 1 and 2). The Lochkovian sections appear to be entirely of shales, unlike those of the Valle syncline where limestone lenses and nodules occur within the shale. Graptolites from at least two levels comprise Monograptus praehercynicus Jaeger, $M$. hercynicus Perner, and Linograptus posthumus (Richter) or ?Abiesgraptus sp.

\section{3b. Valle syncline}

On the northern margin of the El Pintado reservoir (locality 4, Figures 1 and 2) M. hercunicus was recovered by Oczlon (1989) from black limestone lenses or mega-nodules somewhere within the upper part of the 'Upper Graptolitic Shales' of Jaeger and Robardet (1979, section 3, Figure 4). This section corresponds to section 1 of Racheboeuf and Robardet (1986), who recovered the tentaculitoid Homoctenowakia bohemica bohemica from the same beds (see Gessa et al. 1994). The presence of $M$. hercynicus (Fig. 7) has been further confirmed by us, with the addition of a new section south of El Pintado reservoir where two assemblages, a lower one with M.praehercynicus (Fig. 7), L. posthumus and Abiesgraptus sp., and an upper of $M$. hercynicus, have been recovered.

\section{3c. Barrancos-Hinojales domain}

A remarkable record of a post-Lochkovian Devonian graptolite in the Ossa Morena Zone consists of a badly preserved rhabdosome of Monograptus sp. (with hooked thecae: see Figure 5.6 and 5.7) from the middle Verdugo Formation in the Venta del Ciervo section southeast of Cañaveral de León (Huelva Province), Spain (Figure 1, locality 3). Tectonic complications in this locatity (see Figure 2C), however, do not allow the reliable reconstruction of a stratigraphic column. Although the graptolite is not identifiable at the species level, associated late Pragian -early Emsian brachiopods (Racheboeuf and Robardet 1986) and trilobites and ostracodes (Robardet et al. 1991) indicates that the fossiliferous level of the Venta del Ciervo is the equivalent of the lower part of the El Pintado Group of the Cerron del Hornillo and Valle synclines (see Figure 3, column 4) and suggest a possible correlation with the time equivalent of the Monograptus yukonensis Biozone. This represents the youngest graptoloid now known in southwestern Europe.

This is worthy of note, as post-Lochkovian graptolites have until now, been mainly recognized in North America and Asia, the only exceptions in the North Gondwanan region being the Barrandian area in centra] Europe and in the Algerian Sahara (Jaeger 1978, 1988). 


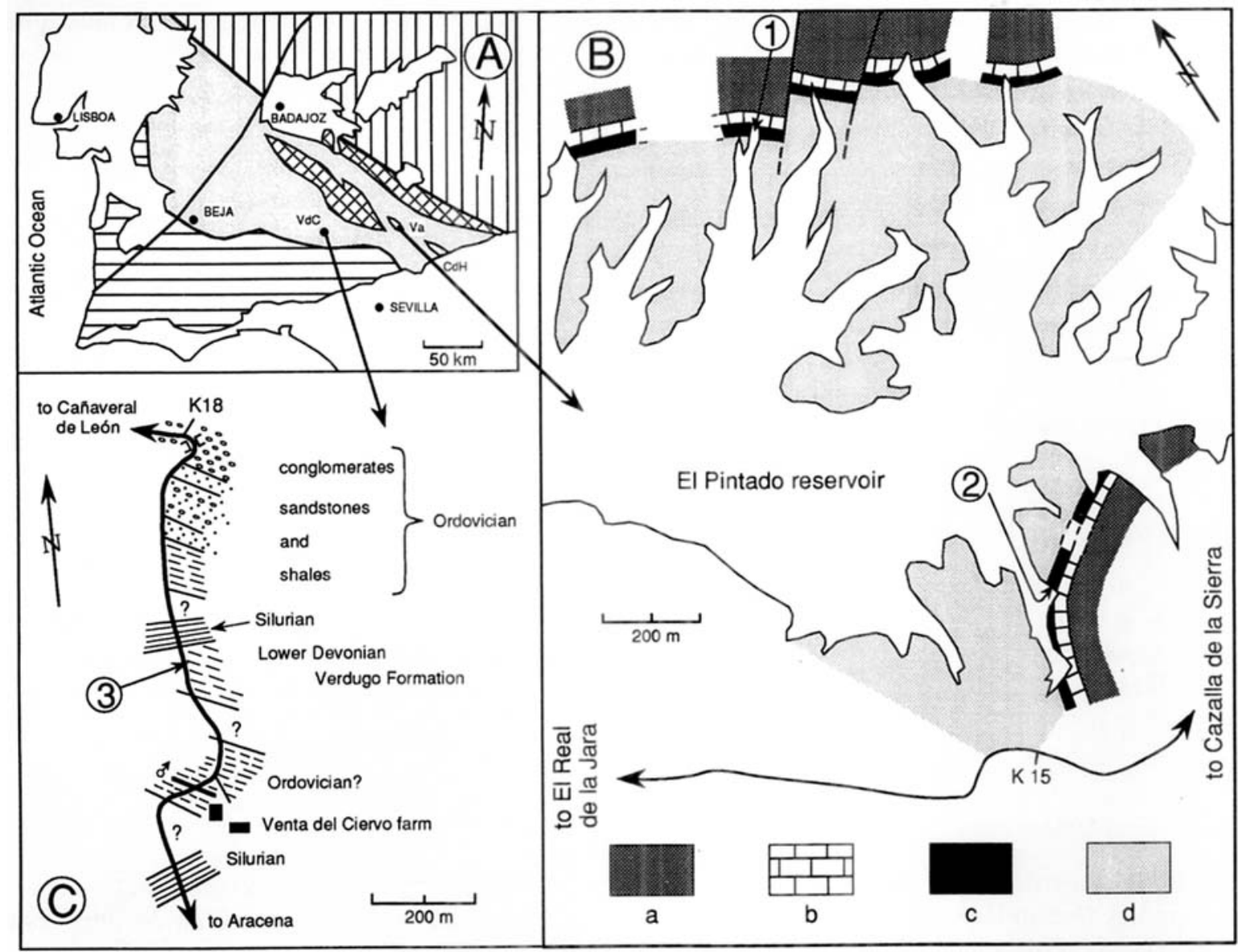

Figure 2. Devonian graptolite localities from the Ossa Morena Zone. (A) Southwestern lberian Peninsula. Vertical hatching, Central Iberian Zone; dotted, Ossa Morena Zone (crossed areas are Precambian antiforms): horizontal hatching, south Portuguese Zone; white, post-Palaeozoic: $\mathrm{CdH}, \mathrm{Va}$ and VdC correspond, respectively, to Cerrón del Hornillo and Valle synclines, and the Vental del Ciervo fossiliferous locality. (B) Devoninan graptolite localities in the Valle syncline. 1, Levels with $M$. praehercynicus (after Oczlon 1989: Gessa et al. 1994): 2, new section with $M$. praeher(ynicus and $M$. hercynicus. Lithostratigraphic units: a. Lower Graptolitic Shales: b. Scyphocrinites limestone; c. Upper Graptolitic Shales; and d, El Pintado Group. (C) Post-Lochkovian graptolite (Monogratus sp.) (locality 3, figure 1) at Venta del Ciervo

\section{PYRENEES}

In the central part of the Spanish Pyrenees, $M$. uniformis, $M$. praehercynicus and $M$. hercynicus were identified by Llopis and Rosell (1968) in black shales and calcareous claystones underlying Devonian limestones near Gerri de la Sal (Lérida Province, Figures 1 and 3 ). The mention of $M$. praehercynicus from below Upper Silurian limestones in the report of Llopis and Rosell (1968), as well as recent findings of Lochkovian conodonts from the w'oschmidti to delta biozones above the graptolite occurrences (Valenzuela-Rios 1990), however, introduces a considerable degree of uncertainty on the validity of the graptolite identification, or of the stratigraphic/tectonic relationships. A thorough review is needed.

\section{CATALONIAN COASTAL RANGES}

Graptolite-bearing shales are known in the basal member of the Olorda Formation, a unit that separates two important carbonate-forming episodes of Pridoli and Lochkovian ages, respectively (Figure: 1, locality 


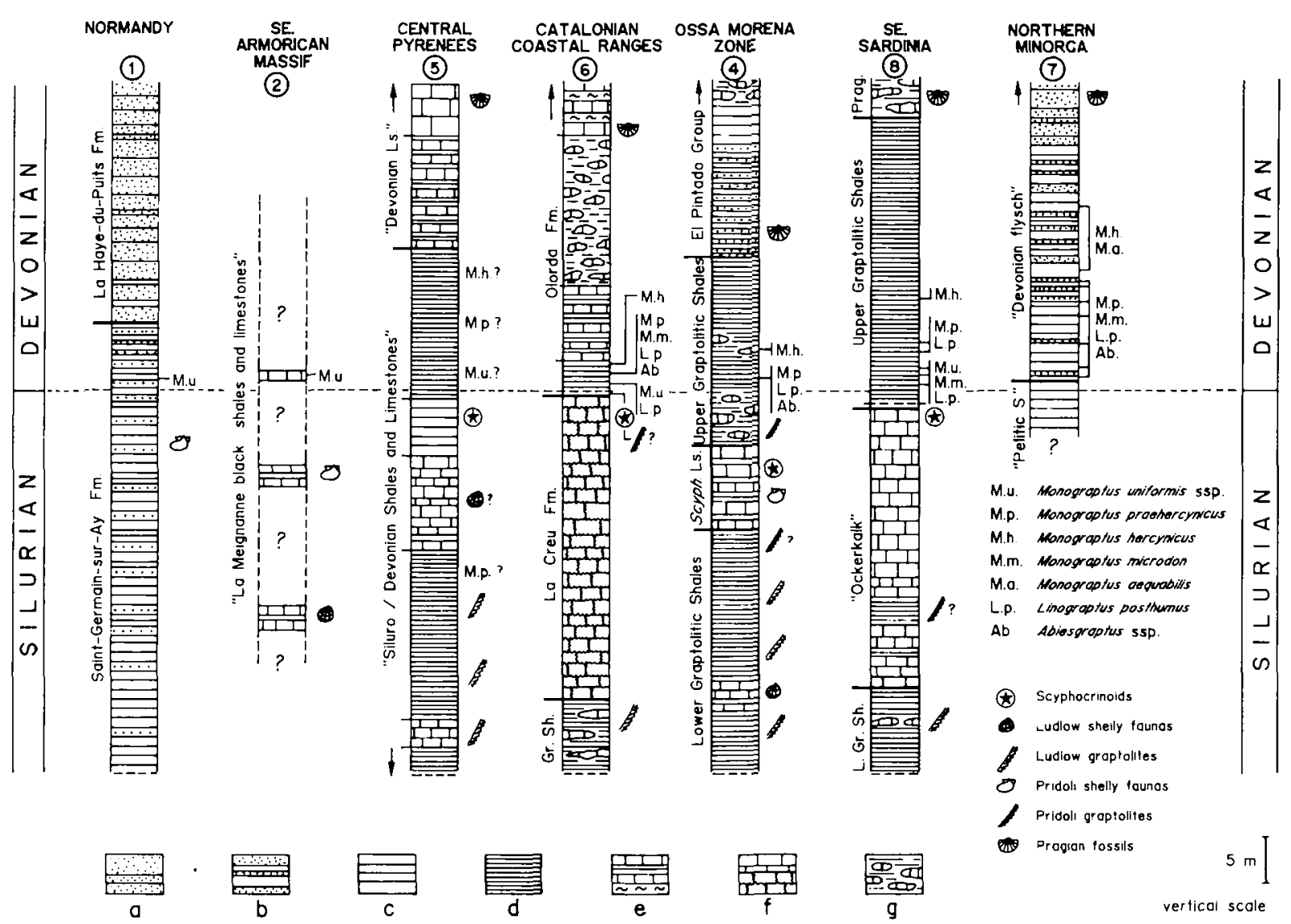

Figure 3. Upper Silurian and Lower Devonian sections from southwestern Europe showing lithostratigraphy and fossil distributions: the section numbers correspond to those in Figure 1. The datum corresponds to the base of the Devonian. Lithological characteristics are as follows: a, sandstones; b, alternating sandstones and shales; c, dark pelites; d, black shales; e. limestones. marls and shales alternating: $f$, limestones and massive nodular limestones; and $\mathrm{g}$, shales with limestones lenses and nodules

6 and Figure 3). Following the initial discovery of $M$. hercynicus and Abiesgraptus sp. in these shales (Greiling and Puschmann 1965), further new localities have been reported. Rickards and Chapman (in Julivert et al. 1985) recognized two assemblages, an older one with $M$. uniformis uniformis or $M$. uniformis angustidens (Fig. 6), and a younger assemblage with $M$. cf. hercynicus and L. posthumus. Recent work by Ferrer et al. (1992) near Barcelona reveals three successive assemblages (graptolite identifications by Jaeger): the uniformis Biozone with $M$. uniformis and L. posthumus; the praehercynicus Biozone, recognized for the first time in that area and containing $M$. praehercynicus, $M$. microdon Richter, L. posthumus, and Abiesgraptus sp.; and a single assemblage of $M$. hercynicus corresponding to the hercynicus Biozone (Figure 4).

In addition to this, the green shales of the uppermost member (Member E) of the Olorda Formation have yielded the first known, but poorly preserved and indeterminable, benthie (dendroid) graptolite from the Devonian of the Iberian Peninsula.

\section{BALEARIC ISLANDS}

These constitute the northeastern extension of the Betic Cordillera of southeastern Spain. The oldest Palaeozoic basement is exposed along the northern coast of the island of Minorca (Figure 1, locality 7). The sequence begins with Lochkovian age turbidites that have yielded graptolites at differing stratigraphic levels 


\begin{tabular}{|c|c|c|c|c|c|}
\hline & $\begin{array}{l}\text { GERMANY } \\
\text { Jaeger } 1988\end{array}$ & \begin{tabular}{|c|} 
RUSSIA \\
Koren 1975
\end{tabular} & $\begin{array}{l}\text { YUKON } \\
\text { Lenz } 1988\end{array}$ & $\begin{array}{c}\text { CZECH REP, } \\
\text { Chlupac } 1988\end{array}$ & SPAIN \\
\hline 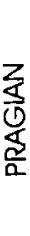 & & $\begin{array}{l}\text { yukonensis } \\
\text { craigensis } \\
\text { fanicus } \\
\text { falcarius }\end{array}$ & $\begin{array}{l}\text { yukonensis } \\
\text { fanicus }\end{array}$ & $\begin{array}{c}\text { yukonensis/ } \\
\text { atopus }\end{array}$ & $\begin{array}{c}\text { Monograptus } \\
\text { sp. }\end{array}$ \\
\hline & $\begin{array}{l}\text { hercynicus } \\
\text { praehercynicus } \\
\text { uniformis }\end{array}$ & $\begin{array}{c}\text { hercynicus } \\
? \\
\text { uniformis }\end{array}$ & $\begin{array}{c}\text { hercynicus } \\
? \\
\text { uniformis }\end{array}$ & $\begin{array}{l}\text { hercynicus } \\
\text { praehercynicus } \\
\text { uniformis }\end{array}$ & $\begin{array}{l}\text { hercynicus } \\
\text { praehercynicus } \\
\text { uniformis }\end{array}$ \\
\hline
\end{tabular}

Figure 4. Lower Devonian graptolite biostratigraphy and biozonal correlations. The suggested biostratigraphic position of the postLochkovian graptolite Monograptus sp. is indicated

(Figure 3). Jaeger (in Bourrouilh 1983) identified a lower assemblage with $M$. praehercynicus, M. microdon and L. posthumus; and an upper assemblage with $M$. cf. hercynicus and $M$. aequabilis Pribyl, the latter fauna being accompanied by a late Lochkovian conodont fauna.

\section{SARDINIA}

Lower Devonian graptolites are well known in southeastern Sardinia (Figure 1, locality 8, and Figure 3) where the entire Silurian to Lochkovian sequences is developed in the classic 'Thuringian triad' i.e. graptolitic black shale and lydite units, separated by 'Ockerkalk' or Scyphocrinites limestones. The 'Upper Graptolitic Shales' overlying the limestones (the so-called calcareous 'intermezzo') have yielded a lower uniformis Biozone assemblage ( $M$. uniformis, $M$. microdon, L. posthumus); a praehercynicus Biozone (M. praehercynicus, L. posthumus); and, lastly, an upper assemblage with M. hercynicus (Helmcke 1973, Jaeger 1976, 1977). Rickards et al. (1995) described M. prachercynicus, L. posthumus and Abiesgraptus (sic) multiramosus Hund from an assemblage referable to either the late uniformis Biozone or the early hercynicus Biozone. These workers also briefly discuss the concept of a praehercynicus Biozone. Lower Devonian graptolites are thus far unknown in the Upper Silurian Lower Devonian sequences of southwestern Sardinia. The biomicritic to biodetrital limestones of the uppermost part of the Fluminimaggiore Formation have yielded cephalopods, scyphocrinoids, bivalves and conodonts, but no graptolites; the Lochkovian age of these strata is based on conodonts of the woschmidti Biozone and on bivalve communities almost identical to those of the Lochkovian of the Prague area, Bohemia (Gnoli et al., 1988, 1990; Olivieri and Serpagli 1990; Křiž and Serpagli 1993).

\section{GENERAL REMARKS}

From the biostratigraphic point of view, the uniformis Biozone has been recognized in Normandy, the southeastern Armorican Massif, the ?Pyrenees and Sardinia. The praehercynicus and hercynicus biozones are documented from the ?Pyrenees, Ossa Morena, Minorca and Sardinia. Only in Sardinia and the Catalonian Coastal Ranges, however, have all three biozones been recognized. Post-Lochkovian graptoloids, albeit poorly preserved, have been recovered from only a single locality in the Ossa Morena zone.

Species diversity is typically very low, generally being represented by monospecific assemblages of the zonal species. Along with Linograptus posthumus and? Abiesgraptus sp., which are present in several of the 

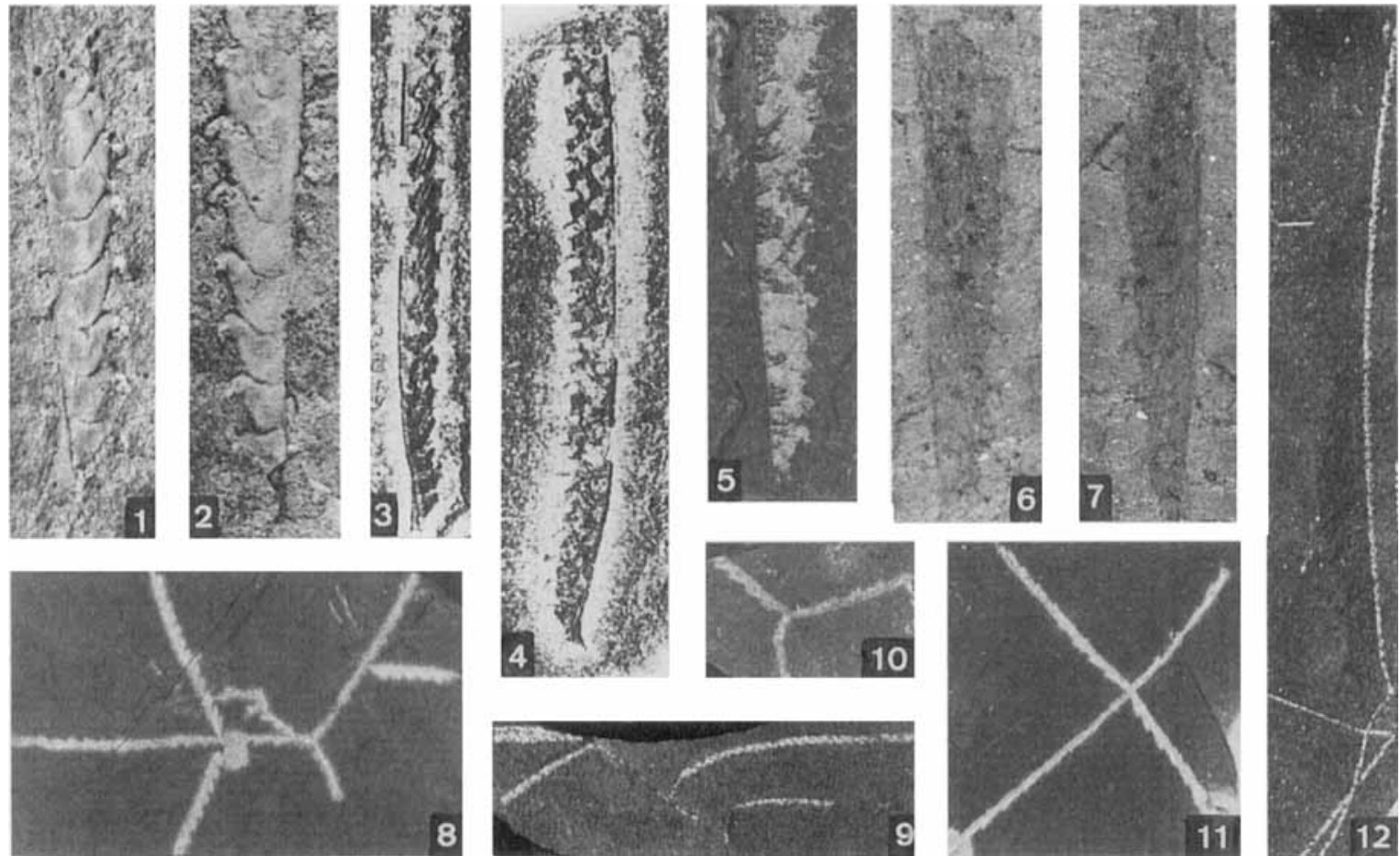

Figure 5. Devonian graptolites from Spain. 1. 2. Monographus hercynicus Perner. from the northern margin of F. Pintado Reservoir (Valle syncline). showing two proximal parts in relief. DPM 3701 and 3702. $\times 7$ : 3. Monograpms aequabilis uequahilis Príbyl. from Minorca, preathercynicus Biozone (from Bourrouilh 1983: pl. 7. figure 3). ×3.2: 4. Monograptus cf. hercymicus Perner, from Minorca. hercinicus Biozone (after Bourrouilh 1983: pl. 7. fig. 1), $\times 3$ : 5. Monogruphus prochercinicus Jaeger, from the new locality south of El Pintado Reservoir (Valle syncline), IPPM 3703. ×4.1:6, 7, Monograptus sp.. from late Pragian early Emsian locality at Cañaveral de León (Huclva), part and counterpart. DPM 3704, ×6: 8. 9. Ahicsgraptus sp.. prochercinicus Biozone $\times 1.25: 8$, from El Pintado Reservoir-south (new locality). DPM 3705, $\times 1.25$; 9. from . Minorca (after Bourrouilh 1983: pl. 2. figure 8). $\times 0.9$ : 10 12. Linograptus pes/humus (Richter). presehercinicus Biozone. proximal parts of three- (10. DPM 3706. $\times 1.9)$ and four-stiped (11. DPM 3707. $\times 2$ rhabdosomes. from El Pintado Resevoir-south (new locality): 12, a more complete rhabosome from Minorea (figured in Bourrouilh 1983: pl. 2. figs. 3. 4). $\times 0.9$

localities, Monograptus microdon is present only on Minorca, the Catalonian Coastal Ranges and Sardinia. and Monograptus aequahilis aecquahilis (Figure 5.3) has been found only on Minorca. By comparison, Jaeger (1988) indicates as many as seven species in the uniformis Biozone, five in the praedeubeli Biozone and four in the hercinicus Biozone of central Europe. all three zones including the very long-ranging taxa $M$. ueguabilis. Linograptus and Ahiesgraptus.

Lower Devonian graptolites of southwestern Europe have been found mainly in rocks typical of outer shelf, "proto-Tethyan" regions similar to those in Thuringia. Bohemia, the Carnic Alps and northwestern Africa. These sequences contain abundant pelagic faunas and are commonly condensed sections, characterized by an overwhelming dominance of argillaceous or argillaceous and carbonate sediments with only minor components of coarser. terrigenous sands.

Although thick. sparsely fossiliferous. shallow water (inner shelf) sequences dominated by coarser clastic sediments are common in the central Iberian and mid-Armorican regions (e.g. Furada-San Pedro, Carazo. Alcolea and Luesma formations, and Cerro Escudero Group, Spain; and the Saint Germain-sur-Ay Formation of the Normandy region. and the Gahard and Plougastel formations. Brittany. France), they have not. with the exception of the Curteret section. yielded graptolites. Certainly, however. other fossils (c.g. chitinozoans; Paris 1981) indicate continuous marine sedimentation from the late Silurian through to the early Devonian. Whether the absence of graptolites signifies environmental exclusion. lack of preservation or a failure to collect rare material is not known. However. it must be again pointed out that in all of the regions in southwestern Europe where Devonian graptolites occur. there is only one exception to 

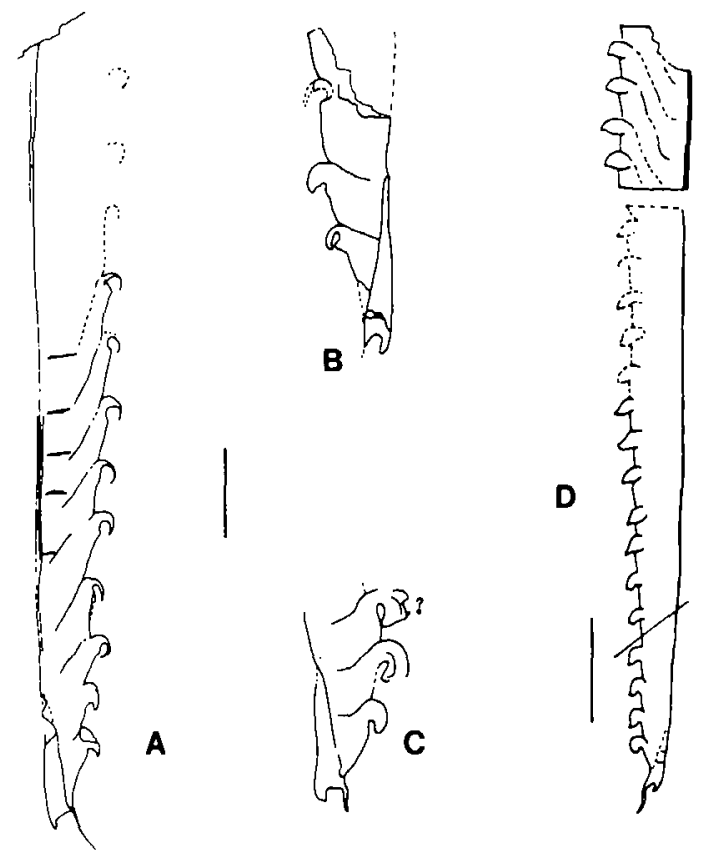

Figure 6. Monograpus uniformis Pribyl from the Catalonian Coastal Ranges, Spain (A-C), and Normandy, France (D). (A) M. uniformis uniformis, flattened specimen from Serra de Miramar: (B. C) M. uniformis angustidens Pribyl, specimens in relief. from Cervello: and (D) $M$. uniformis s.l., from Carteret, proximal and distal parts of two different rhabdosomes on the same slab. (A C redrawn from Rickards and Chapman. in Julivert e't al. 1985. text-figure 4 a, 4e, 4f: and D, after Jaeger and Robardet 1973. text-figure la and $1 \mathrm{~b}$ ). Graphic scale. $3 \mathrm{~mm}$

the fact that the early Silurian to Lochkovian successions consist of almost identical. monotonous euxinic sequences of black shales and lydites with a minor 'intermezzo' of argillaceous limestones within the Pridoli. The presence of a complete graptolitic zonal succession throughout the condensed sequences indicates a low but continuous deposition with a very limited influx of terrigenous particles (Robardet 1982). These characteristics strongly suggest that during Silurian and early Devonian times these regions belonged to the distal-most parts of the North Gondwanan shelf.

\section{ACKNOWLEDGEMENTS}

The considerable impact of the studies of the late H. Jaeger on the elucidation of Early Devonian graptolite faunas of southwestern Europe is acknowledged. Financial support for JCGM for project AMB92-1037C02-01 was through the Comision Interministerial de Ciencia y Technologia (Spain) and that of ACL was through the Natural Sciences and Engineering Research Council (Canada).

\section{REFERENCES}

Babin, C. and Robardet, M. 1974. Molusques Bivalves du Silurien supérieur et de l'extreme base du Dévonien en Normandie. Amales de la Société Géologique du Nord XCIV. 1945.

Bourrouilh, R. 1963. Découverte de Silurien à Graptolites a Minorque (Baléares, Espagne). Compte Renclu sommuire des séances de la Societé géologique de France 10, 344-345.

_- - 1983. Fstratigrafia. Sedimentología y Tectónica de la Isla de Menorca y del Noreste de Mallorca (Baleares). La terminación nororiental de las Cordilleros Béticas en el Mediterráneo occidental. Memorias del Instilluto Geoligico y Minero de España 99. $672+99 \mathrm{pp}$. 


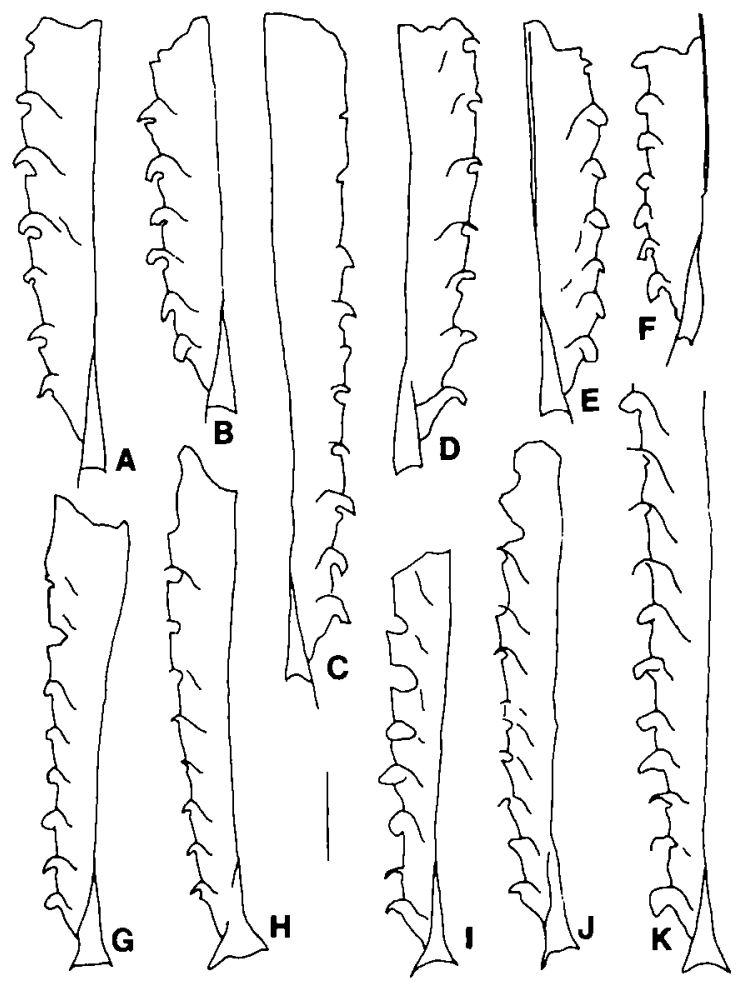

Figure 7. Devonian graptolites from F. Pintado Resevoir-south (new locality). (A-F) Monogratus praeher(ynicus Jaeger. DPM 3708. 3709. 3710. 3711. 3712. 3713: (G-K) Monograptus herchnicus Perner. DPM 3714. 3715. 3716, 3717. 3718. Graphic scale 2 mm

Chlupač, I. 1998. The Devonian of Czechoslovakia and its stratigraphic significance. In: McMillan. N. J., Embry, A. F. and Glass, D. J. (eds) Devomian of the World. Vol. I. Canadian Society of Petroleum Geologists. Memoir 14, 481 497.

Ferrer, E., Magrans, J. and Mañé, R. 1992. Euriptèrids (merostomats) del Devoniàn inferior de Bruguers (Gava) i Santa Creu d' Olorda (Sant Feliu de Llobregat). I Trobada d'Estudiosos de Garraf. Monografies Diputació de Barcelona 19, 3338.

Gessa, S., Truyols-Massoni, M. and Robardet, M. 1994. Quantitative analysis of Homoctenowakia bohemica bohemica (Tentaculitoids) from the Lochkovian of the Valle syncline, Ossa Morena Zone, Spain. Revista Española de Paleontologia 9. 203210.

Gnoli, M., Křižz, J., Leone, F., Olivieri, R., Serpagli, E. and Štorch, P. 1990. Lithostratigraphic units and biostratigraphy of the Silurian and carly Devonian of Southwest Sardinia. Bolletino della Societa Paleontologica ltaliana 29, 11 - 23.

- - Leone, F., Olivieri, R. and Serpagli, E. 1998. The Mason Porcus Section as reference section for uppermost Silurian Lower Devonian in SW Sardinia. Bolletino della Società Paleontologica Italiana 27, 323-334.

Greiling, L. and Puschmann, H. 1965. Die Wende Silurium/Devon aus St. Creu d'Olorde bei Barcelona (Katalonien). Senckenhergiana lethaea 46. 453-457.

Heimcke, D. 1973. Schichtgebundene NE-Metall- und F-Ba-Lagerstätten im Sarrabus-Gerrei-Gebiet, SE-Sardinien. II. Bericht. Zur Statigraphic des Silur und Unterdevon der Lagerstättenprovinz Sarrabus-Gerrei. Neues Jahrbuch für Geologie und Paläontologie. Monatshefte 9. 529544.

Jaeger, H. 1976. Das Silur und Unterdevon von Thuringischen Typ in Sardinien und Seine regionalgeologische Bedeutung. Nova Acta Leopoldina. 45, 263-299.

- - 1977. The Silurian-Devonian boundary in Thuringia and Sardina. In: Martinsson, A. (ed.) The Silurian-Devonian Boundary'. International Union of Geological Sciences. Series A 5. 117125.

- - 1978. Late graptoloid faunas and the problem of graptoloid extinction. Acta Palaeontologica Polonica 23, 497521.

- - 1988. Devonian Graptoloidea. In: McMillan. N. J., Embry. A. F. and Glass, D. J. (eds) Devonian of the World. Vol. III. Canadian Society of Petroleum Geologists, Memoir 14, 431438.

_- _ and Robardet, M. 1973. Déouverte de Monograptus uniformis Pribyl, Graptolite gedinnien, dans les "schistes et quartzites siluro-dévoniens" du Cotentin (Normandie, France). Comptes Rendus de l'Acudémie des Sciences de Puris, Série D 277. $2129-2132$.

_ — and Robardet, M. 1979. Le Silurien et le Dévonien basal dans de Nord de la Province de Séville (Espagne). Geobios 12 , $687-714$.

- - Doré, F. and Philippot, A. 1967. Présence du Budnanien en Normandie dans le synclinal d'Urville (Calvados). Courte description et discussion des Graptolites de cet étage provenant du sondage du Quesnay (Calvados). Mémoires du Bureau des Recherches Géologiques et Minières 33, 35-49.

Julivert, M., Durán, H., Rickards, R. B. and Chapman, A. J. 1985. Siluro-Devonian graptolite stratigraphy of the Catalonian Coastal Ranges. Acta Geologica Hispànica 20. $199-207$. 
Koren, T. N. 1975. Farly Devonian monograptids of the telleri biozone in Urals--Tien Shan fold belt. Acta Geologica Polonicu 25,1 - 24.

Křiž, J. and Paris, F. 1982. Ludlovian. Pridolian and Lochkovian in La Meignanne (Massif Armoricain): biostratigraphy and correlations based on Bivalvia and Chilimozoa. Geobios 15. 391-421.

- - and Serpagli, E. 1993. Lpper Silurian and Lowermost Devonian Bivalvia of Bohemian type from South-Western Sardinia. Bolletino della Societa Paleontolgica Italiana 32, 389347.

Lenz, A. C., 1988. Revision of Lpper Silurian and Lower Devonian graptolite biostratigraphy and morphological variation in Monograplus, rukonensis and related Devonian graptolites. northern Yukon. Canada. Ir: McMillan, N. J.. Embry. A. F. and Glass. D. J. (eds) Devonian of the World. Vol. III. Canadian Society of Petroleum Geologists, Memoir 14. 439..447.

Llopis Lladó, N. and Rosell Sanuy, J. 1968. Algunas aportaciones a la estratigrafia del Silúrico-Devónico de "las Nogueras" al E de Gerri de la Sal (Lérida). Acta Geoligica Hispanica 3, 113-116.

Oczlon, M. 1989. Fazies und Fauna im Silur und Dovon des "Valle" (Provinz Sevilla. SW-Spanien). Mit einer üherregionalen Betrachnong der Mithledevom-Schichtlïcke. Diplomarbeit Lniversität Heidelberg.

Olivieri, R and Serpagli, E. 1990 . Latest Silurian-early Devonian conodonts from the Mason Porcus Section near Fluminimaggiorre, southwestern Sardinia. Bollerino della Sociera Paleonologica Italiana 29,5976.

Paris, F. 1981. I es Chitinozaires dans le Paléozoïque due Sud-Ouest de l'Europe (Cadre géologique-Etude systematiqueBiostratigraphic). Mémoires de la Société géologique et minéralogique de Bretagne 26. 1412.

Péneau. J. 1944. Présence de Graptolithes dans le Gothlandien de la Meignanne. Bulletin de la Société d'Eudes Scienifiques d'Angers, nownelle. Sirie, 68 73e années, 1938 1943, 2729.

Philippot, A. 1950. Les graptolites du Massif Armoricain. Etude stratigraphique et paléontologique. Mémoires de la Société géologique et minéralogique de Bretagne 8. 1-295.

Racheboeuf, P. R. and Robardet, M. 1986. Le Pridoli et le Dévonien inférieur de la Zone d'Ossa-Morena (Sud-Ouest de la Péninsule ibérique). Etude des Brachiopodes. Geologica et Palceontologica 20. 1137.

Richards, R. B., Holland, C. H. and Serpagli, E. 1995. Aspects of Silurian and Lower Devonian graptolite faunas and stratigraphy in southern Sardinia. Bolletino della Sociera Paleomologica lialiana 34, 6780.

Robardet, M. 1982. The Silurian-earliest Devonian suceession in South Spain (Ossa Morena Zone) and its paleogeographical significance. IGCP No. 5 Newsleter 4. 72-77.

_- Gross-Uffenorde, H., Gandl, J. and Racheboeuf, P. R. 1991. Trilobites et Ostracodes du Dévonien inférieur de la Zone d'OssaMorena (Espagne). Geobios 24, 333-348.

Valenzuela-Rios, J. I. 1990. Lochkovian conodonts and stratigraphy at Gerri de la Sal (Pyrenees). Courier Forschumgsinstitut Senckenterg 118. $53-63$. 